https://doi.org/10.47529/2223-2524.2020.4.5

\title{
Evaluation of the effectiveness of inveterate Achilles tendon rupture V-Y plasty with immediate subsequent weight-bearing and rehabilitation. Case study
}

\author{
Bartłomiej Kacprzak, Mateusz Styk, Natalia Siuba-Jarosz*
}

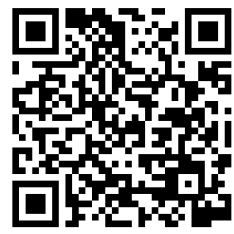

Orto Med Sport, Łódź, Poland

\section{ABSTRACT}

In our paper, we would like to present two cases of treatment of the Achilles tendon ruptures by means of surgical V-Y technique, and implementation of immediate rehabilitation and weight-bearing.

V-Y plasty on ruptured tendons was performed. The continuity of the tendon was restored. The sheath of the tendon was stitched together. Dressing was put on; the foot was immobilized in a Walker-type shoe in pes equinus with heel pads and compression underwear. From the first hour after the procedure, the wound area was cooled with a Game Ready device.

From the first day after the procedure, both patients were allowed to apply full weight to the limb in the shoe. The crutches were put away as soon as possible. Rehabilitation began right away on the next day; during its course, attempts were made to reduce the use of the shoe to a minimum and to achieve the full range of foot motion as soon as possible. In both patients, the full range of motion was reached approximately 2 weeks after the surgery.

The video support for the article is available at: https://youtu.be/bi3xuwOT9vs

Keywords: Achilles tendon, V-Y plasty, immediate rehabilitation

Conflict of interests: the authors declare no conflict of interest.

Ethics approval and consent to participate: the study was also approved by the Bioethical Commission at the Medical University of Lodz.

For citation: Kacprzak B., Styk M., Siuba-Jarosz N. Evaluation of the effectiveness of inveterate Achilles tendon rupture V-Y plasty with immediate subsequent weight-bearing and rehabilitation. Case study. Sportivnaya meditsina: nauka i praktika (Sports medicine: research and practice). 2020;10(4):22-29 (In Russ.). https://doi.org/10.47529/2223-2524.2020.4.5

Received: 11 November 2020

Accepted: 21 December 2020

Online first: 4 February 2021

Published: 11 March 2021

* Corresponding author

\section{Оценка эффективности V-Y сухожильной пластики с немедленным последующим переносом веса тела на ногу и реабилитацией при застарелом разрыве ахиллова сухожилия. Клинический случай}

\author{
Б. Кацишак, М. Стик, Н. Сиуба-Ярош
}

Orto Med Sport, Лодзь, Польша

PEЗЮME

В нашей статье мы хотели бы представить два случая лечения разрывов ахиллова сухожилия хирургическим методом V-Y сухожильной пластики, а также осуществление немедленного переноса веса тела на ногу и реабилитации.

У пациентов была произведена V-Y пластика разорванных сухожилий, в ходе которой восстанавливалась их целостность. После операции была наложена повязка, стопа была иммобилизована в обуви Walker-type с применением подпяточника и компрессионного белья. С первого часа после процедуры область раны охлаждали устройством Game Ready.

С первого дня после процедуры обоим пациентам разрешалось полностью переносить вес на конечность в обуви, костыли убирались как можно скорее. Реабилитация начиналась сразу на следующий день. В ходе этого курса были предприняты попытки свести использование обуви к минимуму и как можно скорее достичь полного диапазона движений стопы. У обоих пациентов полный диапазон движений был достигнут примерно через 2 недели после операции.

Видеосопровождение к статье доступно по ссылке: https://youtu.be/bi3xuwOT9vs

Ключевье слова: ахиллово сухожилие, V-Y сухожильная пластика, немедленная реабилитация 
Конфликт интересов: авторы заявляют об отсутствии конфликта интересов.

Заключение этического комитета: исследование было одобрено Комиссией по биоэтике Лодзинского медицинского университета.

Для цитирования: Кацпшак Б., Стик М., Сиуба-Ярош Н. Оценка эффективности V-Y сухожильной пластики с немедленным последующим переносом веса тела на ногу и реабилитацией при застарелом разрыве ахиллова сухожилия. Клинический случай. Спортивная медицина: наука и практика. 2020;10(4):22-29. https://doi.org/10.47529/2223-2524.2020.4.5

Поступила в редакцию: 11.11 .2020

Принята к публикации: 21.12.2020

Online first: 04.02 .2021

Опубликована: 11.03 .2021

* Автор, ответственный за переписку

\section{Introduction}

The Achilles tendon is the most durable, mechanically strongest tendon of the human body. It is made up of the gastrocnemius calf and soleus muscle, and has its adhesive on the calcaneal tuber [1].

From a biomechanical point of view, the heel tendon is the main ankle joint flexor (the calf gastrocnemius muscle is a two-joint muscle; not only it is responsible for plantar flexion but also supports knee joint flexion, while the soleus muscle acts only on the ankle)[2]. Despite its resistance, the Achilles tendon is the most frequently ruptured tendon. Most of the ruptures (about $75 \%$ ) occur during recreational activities, more often in men between 30-40 years of age, especially when playing soccer, tennis or basketball. However, $25 \%$ of ruptures may occur in patients leading a sedentary lifestyle [3]. Although Achilles tendon injuries are common and generally do not make diagnosis very difficult to an experienced clinician, as much as $20 \%$ of acute ruptures are misdiagnosed, leading to inveterate ruptures [4].

Inveterate Achilles tendon rupture is the term used for ruptures that last for 4-6 weeks after the injury due to misdiagnosis or ineffective treatment [5]. Symptoms of chronic rupture include: chronic pain, limping, weakening of the calf muscles and inability to lift the foot. They definitely worsen the patients' quality of life. Overlooking a rupture of the Achilles tendon (e.g., in torsional ankle joint traumas or malleolus fractures) leads to the contraction of the muscle belly and spacing of the stumps of the tendon. In order to achieve the appropriate length of the tendon, the surgeon extends it by means of "V-Y" technique performed above its rupture. For this purpose, the surgeon incises the tendon in the shape of the letter " $V$ ", then moves the ends away from each other and stitches the tendon so that the edges of the wound take the shape of the letter "Y".

In our paper, we would like to present two cases of treatment of the Achilles tendon ruptures by means of surgical $\mathrm{V}-\mathrm{Y}$ technique, and implementation of immediate rehabilitation and weight-bearing.

\section{Description of cases}

1. A 44-year-old female patient reported to the Orto Med Sport Clinic on September 3, 2019 due to severe pain in the Achilles tendon. From the anamnesis, it turned out that in April 2019 the patient had undergone surgery to remove a Haglund's deformity, followed by placing a plasterboard splint, in another center. In June 2019, the patient had experienced severe pain, and then had proceeded to a followup visit to the doctor who had performed the procedure. Following an ultrasound examination, it turned out that the Achilles tendon was completely ruptured. Conservative treatment, including a series of injections of glucocorticoids, was ordered. Surgical treatment had been refused. The treatment applied for 3 months did not bring any improvement. The pain was intensified, the patient could not put any strain on this limb, walk without crutches; nevertheless the patient was assured that it was a normal condition. In September, during a visit to Orto Med Sport, the patient was physically examined, and an ultrasound examination revealed: inability to stand on toes, positive Thompson test, palpable loss in the course of the tendon, and loss of plantar flexion. The patient was diagnosed with total rupture of the Achilles tendon. The patient was qualified for V-Y plastic surgery of the Achilles tendon. After performing a medial incision, the patient was diagnosed with complete tear of the tendon. The presence of numerous deposits was observed, which are associated with frequent GKS injections. The deposits were removed and tissues were mobilized. V-Y plasticity was performed. The continuity of the tendon was restored. The sheath of the tendon was stitched together. Dressing was put on; the foot was immobilized in a Walker-type shoe in pes equinus with heel pads and compression underwear. From the first hour

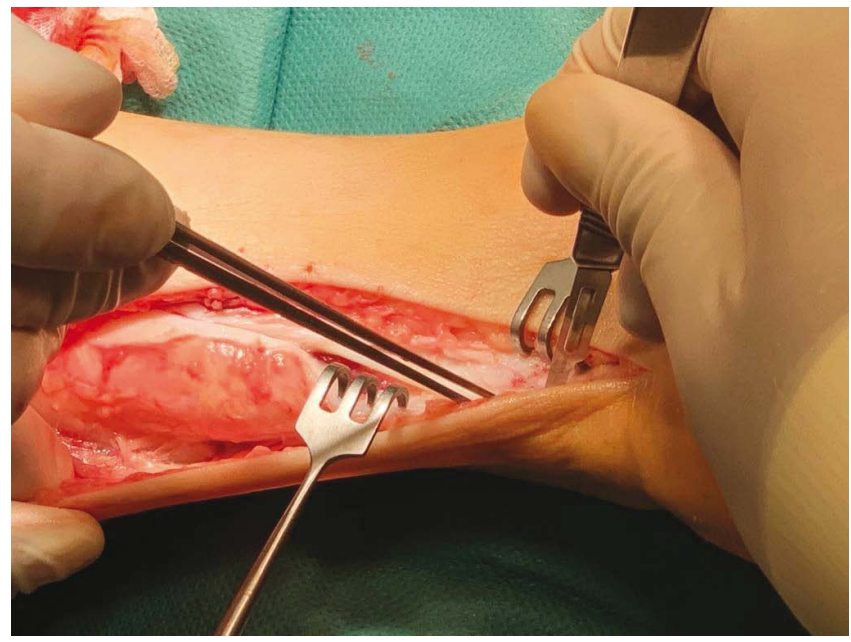

Fig. 1. Medial cutting

Рис. 1. Медиальный разрез 


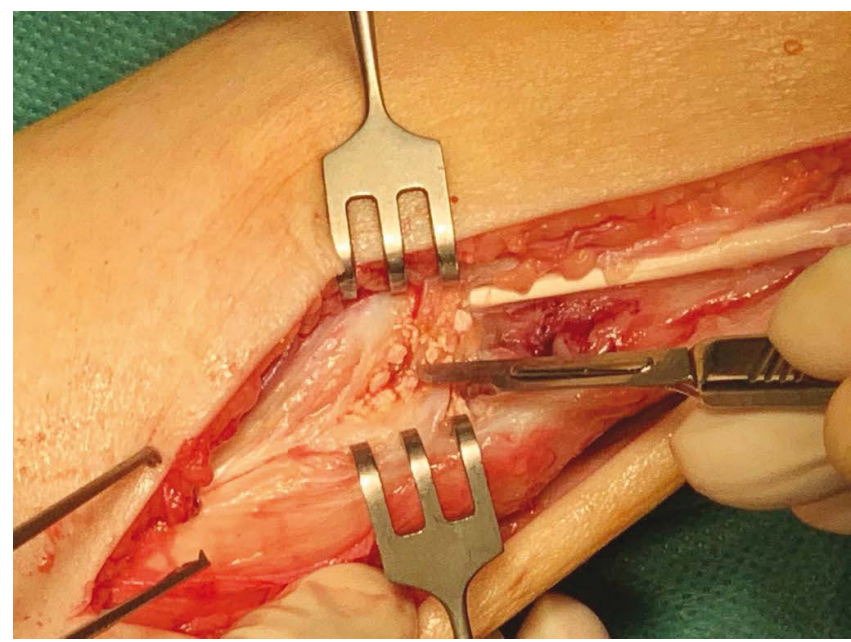

Fig. 2. Visible steroid deposits

Рис. 2. Видимые стероидные отложения

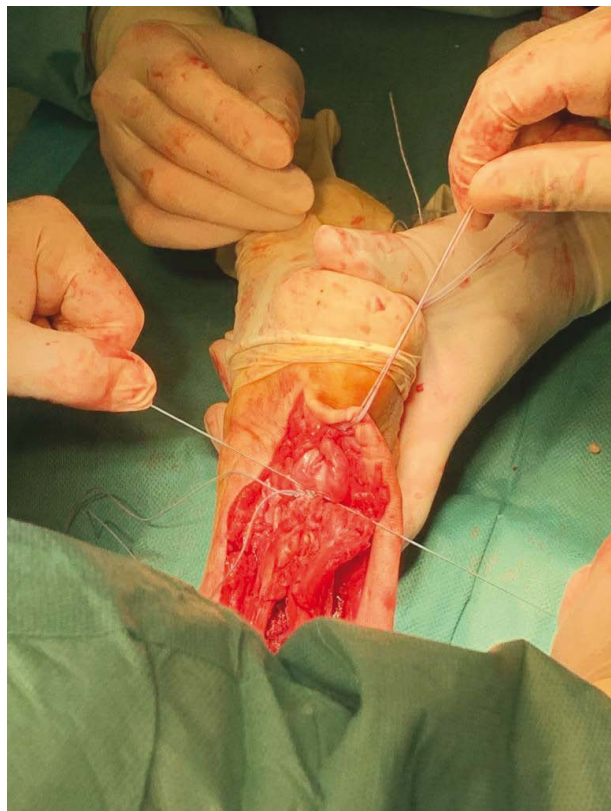

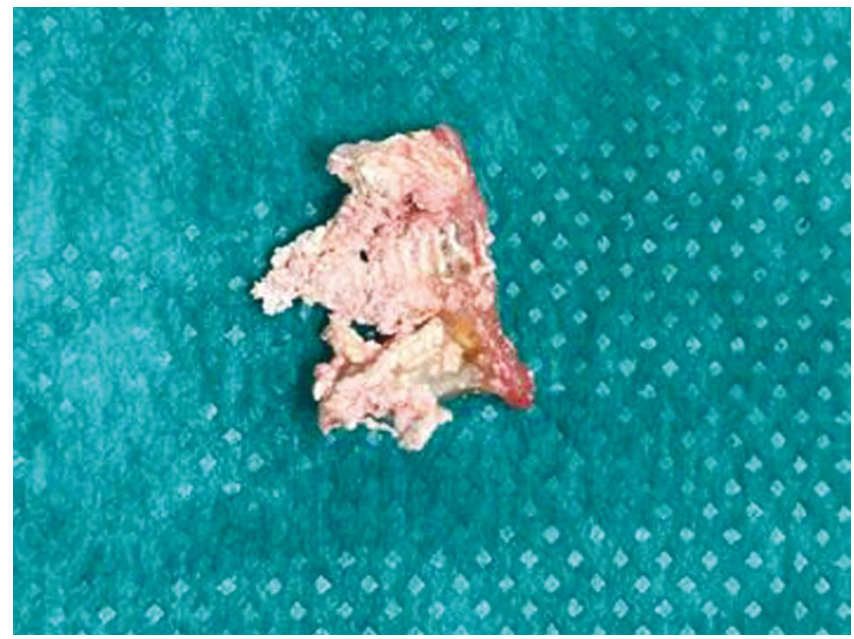

Fig. 3. Removed steroid deposit

Рис. 3. Удаленное стероидное отложение

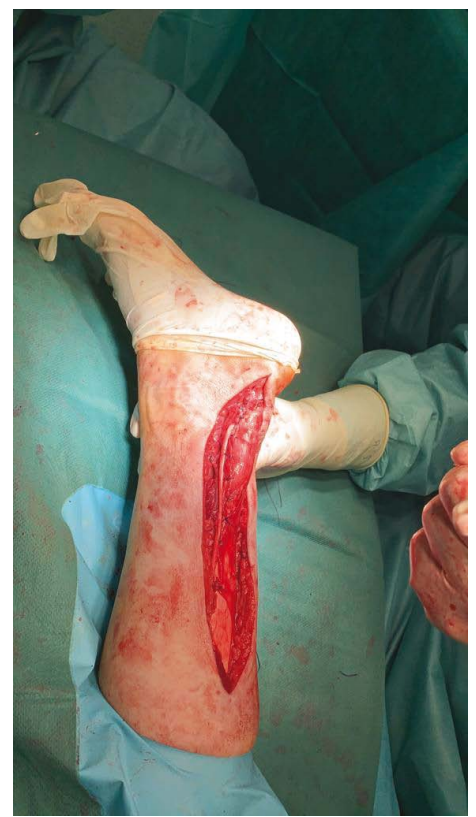

Fig. 4. Subsequent stages of the procedure, restoration of tendon continuity

Рис. 4. Последующие этапы операции, восстановление целостности сухожилия

after the procedure, the wound area was cooled with a Game Ready device.

2. A 43-year-old female patient reported to Orto Med Sport on June 29, 2018 due to the failure of Achilles tendon rupture surgical treatment in another center. The patient was provided with a plaster dressing on admission. Physical examination revealed inability to stand on the toes, positive Thompson test, palpable edema and hematoma in the tendon area and impairment of plantar flexion. The patient reported severe pain, both during exercise and at rest. It was recommended to perform revision surgery involving the V-Y technique as well. The surgery took place on July 2, 2018. The incision was performed on the medial side of the tendon. The scar from tendon suturing was reached; there was a bunch of bridging sutures, which were incorrectly fastened and did not bring together the stumps of the tendon. The Achilles tendon was found to be completely ruptured/unhealed with a $12 \mathrm{~cm}$ gap between the stumps. The tissues were cleaned and mobilized. The stumps of the tendon had scarring lesions. Surgical sutures left after prior plasty were removed. The wound was rinsed. V-Y plasty was performed. Additionally, modeling bridging sutures were put on and the continuity of the tendon was restored. Then the sheath of the tendon was sutured. Afterwards, a sterile, compression dressing was put on. The foot was immobilized in a Walker-type shoe in pes equinus with heel pads and compression underwear. From the first hour after the procedure, the wound area was cooled with a Game Ready device. 

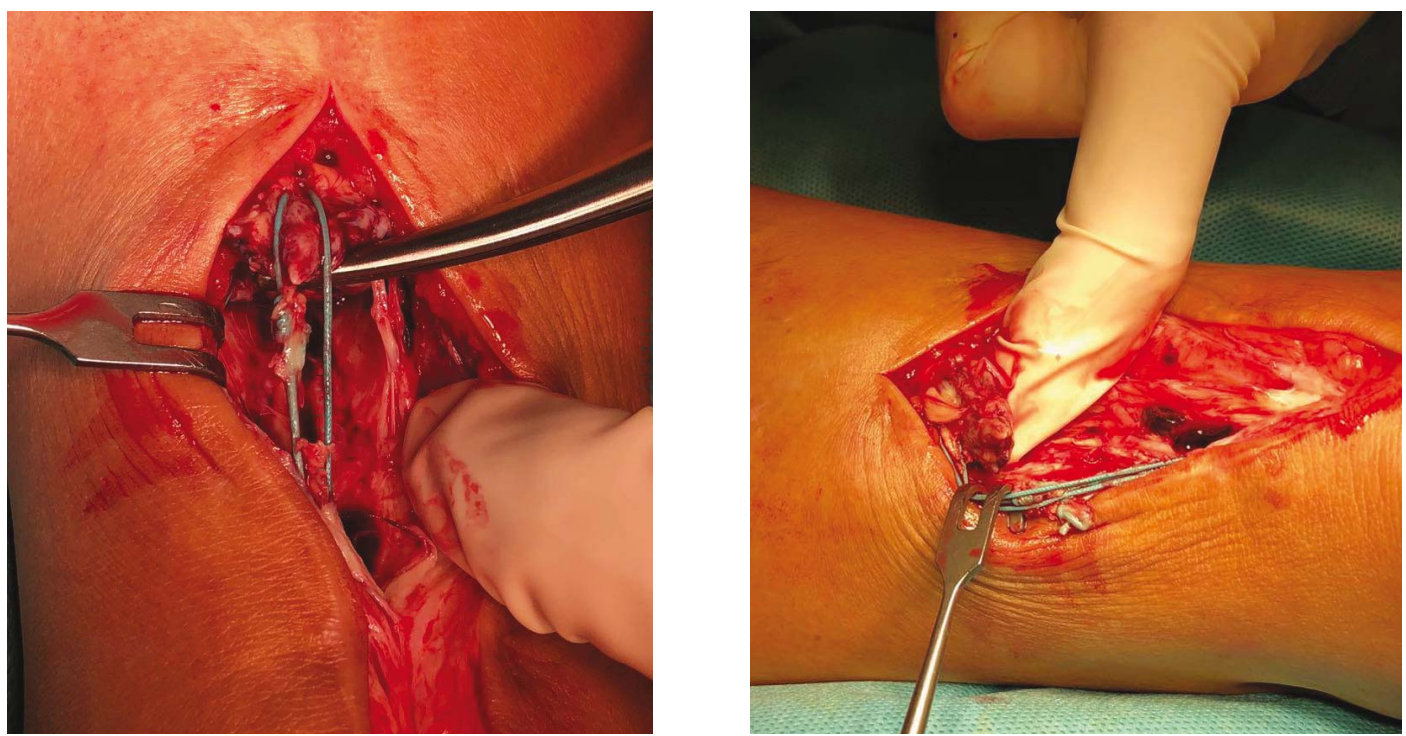

Fig. 5. Visualization of badly located bridging sutures, not performing their function, stumps of tendons loosely hanging in space Рис. 5. Визуализация плохо расположенных мостиковых швов, не выполняющих свою функцию, свисающих культей сухожилий

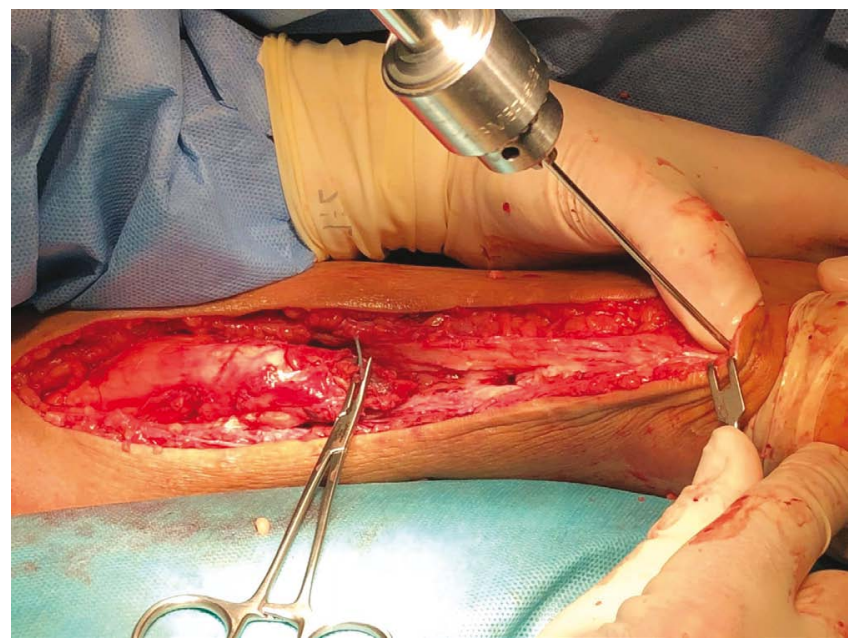

Fig. 6. Visible $12 \mathrm{~cm}$ loss in tendon continuity

Рис. 6. Видимая потеря целостности сухожилия на протяжении 12 см

\section{Course of rehabilitation}

From the first day after the procedure, both patients were allowed to apply full weight to the limb in the shoe. The crutches were put away as soon as possible. Rehabilitation began right away on the next day; during its course, attempts were made to reduce the use of the shoe to a minimum and to achieve the full range of foot motion as soon as possible. In both patients, the full range of motion was reached approximately 2 weeks after the surgery. The time of use of the walking shoe was 4-6 weeks. Every 2 weeks further heel pads were removed, bringing the foot position closer to the neutral one. Patients had no restrictions on vital activity from the first days after the surgery.

From the first day after the surgery, functional training was performed in our rehabilitation room under the strict supervision of physiotherapists and physician. The patients

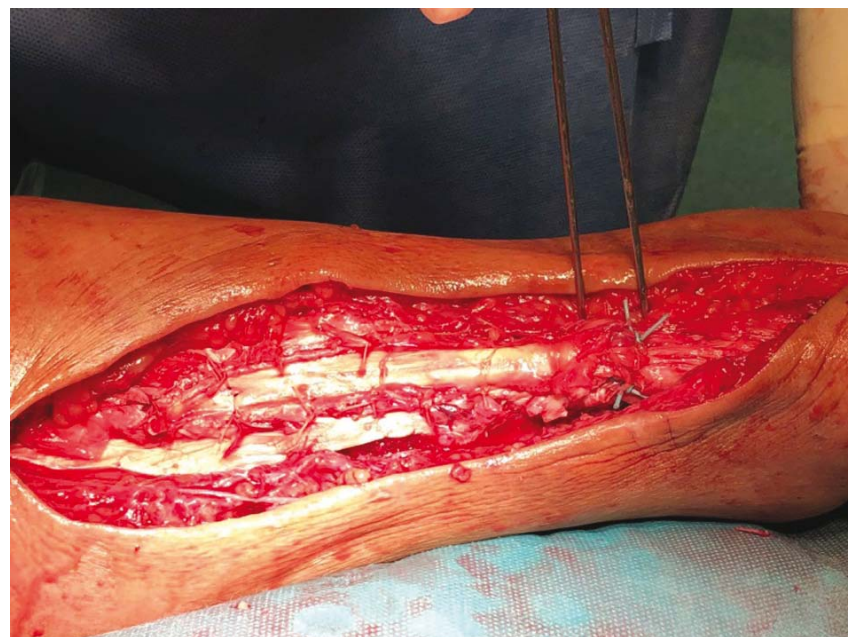

Fig. 7. Post-plasty photo, reconstructed tendon continuity Рис. 7. Фотография после пластики, восстановленная целостность сухожилия

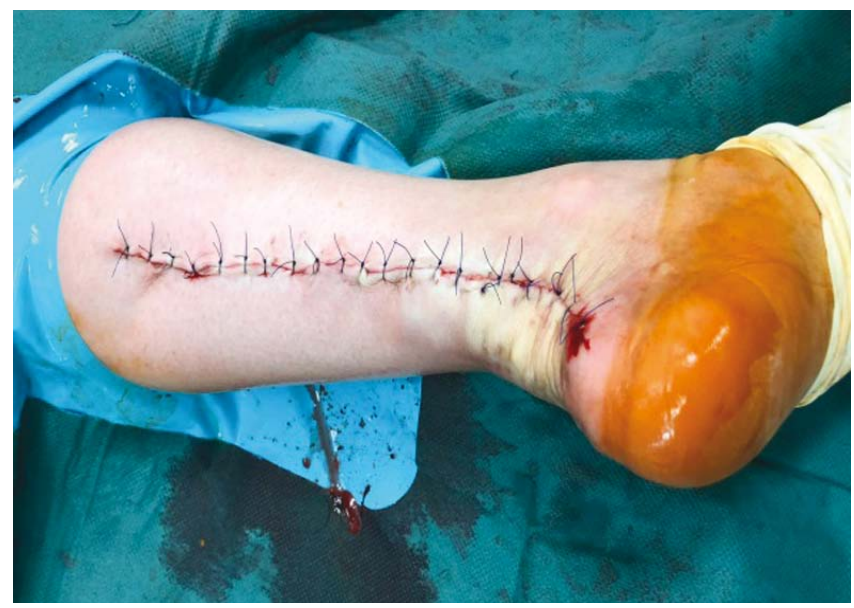

Fig. 8. Stitched wound

Рис. 8. Ушитая рана 

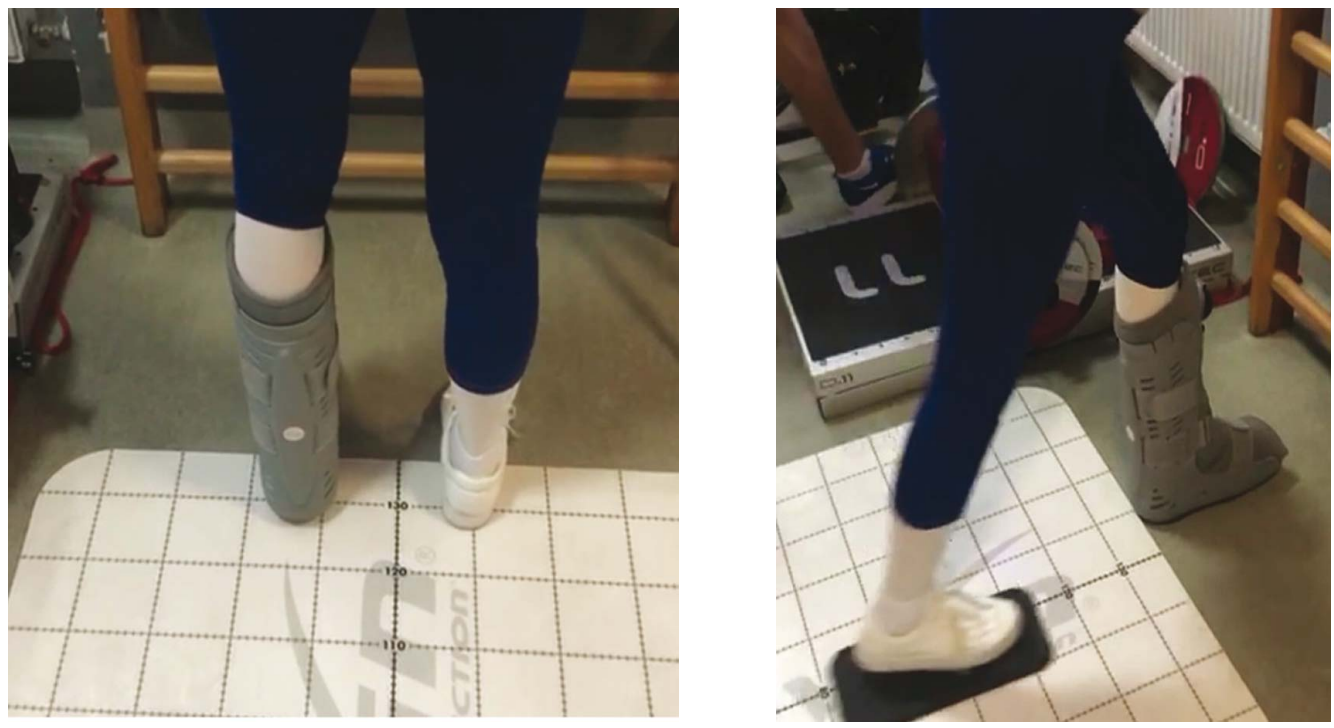

Fig. 9. First week after the operation, rehabilitation under full weight load Рис. 9. Первая неделя после операции, реабилитация с полной нагрузкой
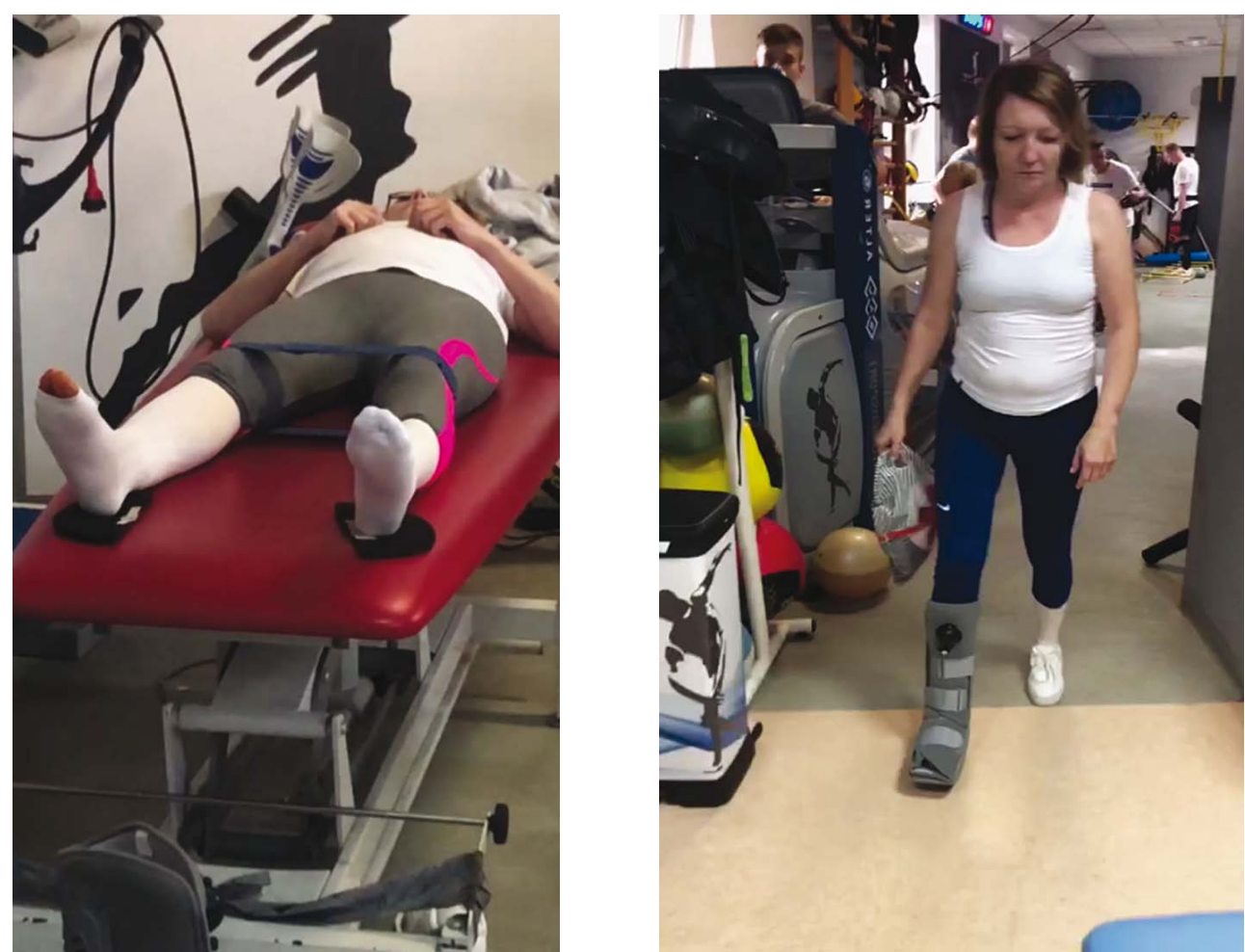

Fig. 10. First week after the operation, rehabilitation under full weight load

Рис. 10. Первая неделя после операции, реабилитация с полной нагрузкой

performed resistance, eccentric-concentric exercises, using their own body weight. Under supervision, the patients learned to perform normal movement patterns. We put a lot of emphasis on performing proprioception exercises on unstable ground. The whole was complemented by manual work performed by the physiotherapist: scar mobilization, anatomy trains alignment and work with fascia. Stretching and rolling of muscles and fascia after the exercise is also of great importance.
The whole of rehabilitation was complemented by regeneration procedures such as Game Ready, flossing, dry needling, lymphatic drainage, electrostimulation, hyperbaric chamber.

Patients had control visits in the following regime - one week, 2 weeks, one month, 2 months, 4 months, and 6 months after the surgery. The treatment of the former patient was completed on March 31, 2020, and the treatment of the latter patient was completed on February 5, 2019, i.e. approx. 
6 months after the surgery. To date, they do not report any symptoms and have no restrictions on physical activity. Their comfort of life has definitely improved.

\section{Discussion}

Despite the fact that the Achilles tendon rupture is one of the most common lower limb injuries, as the above cases show, doctors still make mistakes in their diagnosis and treatment. There is still a lot of controversy about surgical vs conservative treatment [6].

In the meta-analysis by Dengue et al, 8 randomized trials involving 762 patients were analyzed [7]. Overall, 14 out of 381 surgically treated patients and 37 conservatively treated patients experienced a recurrent tendon rupture. Statistical analysis revealed that recurrent ruptures were significantly less frequent in the group treated with surgery than in those undergoing conservative treatment. There were no significant statistical differences between the prevalence of venous thrombosis, the percentage of patients who returned to sports, the range of ankle motion, or physical activity between the two groups. Therefore, the authors concluded that surgical treatment seems to be a better long-term choice for patients with this issue.

As for the very choice of V-Y plasty for treatment in the cases of the patients we have presented, i.e., already inveterate ligament ruptures, our choice, in addition to the good outcomes for them, also supports the study by Lin Yang-jing et al., who undertook to evaluate the outcomes of inveterate Achilles tendon rupture treatment in 20 patients operated by this method in their clinic. However, their postoperative management differed significantly from ours. Patients were applied a plaster cast below the knee for 4 weeks. During this time, the patients could only perform non-weight-bearing exercises with crutches. After 4 weeks, partial weight-bearing on the leg was introduced, and the patients returned to their normal activities and to applying full weight load on the operated leg only 10-12 weeks after the surgery. The average follow-up time was 32.8 months, and none of the patients experienced a recurrent Achilles tendon rupture nor developed serious postoperative complications [5].

Long-term post-surgical effects of inveterate Achilles tendon rupture V-Y plasty were also presented by Guclu et al. in their work [8]. They performed this operation in 21 patients

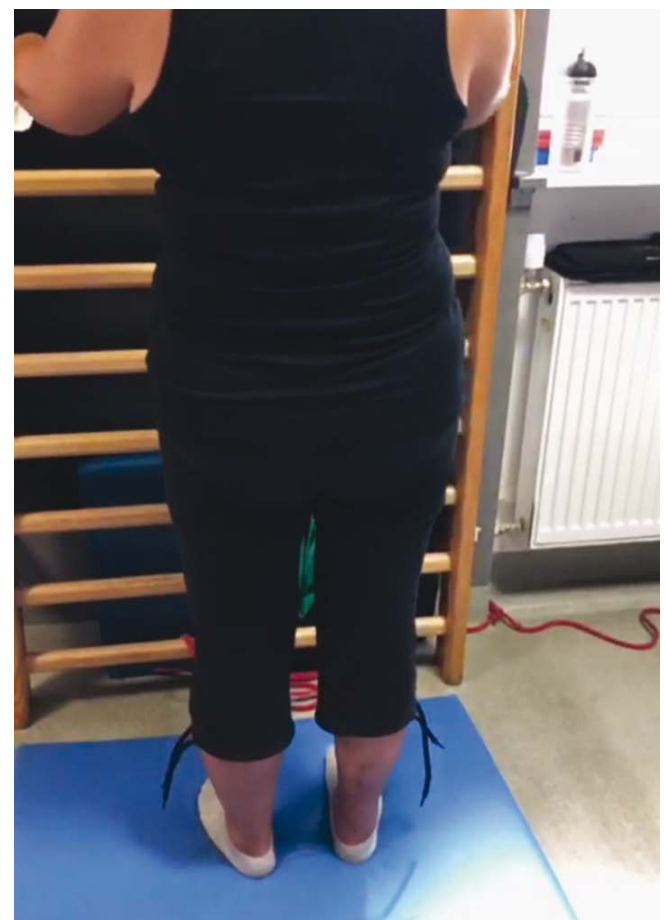

Fig. 11. Two weeks after the Achilles revision, rehabilitation with full weight load

Рис. 11. Через две недели после ревизии ахиллова сухожилия, реабилитация с полной нагрузкой
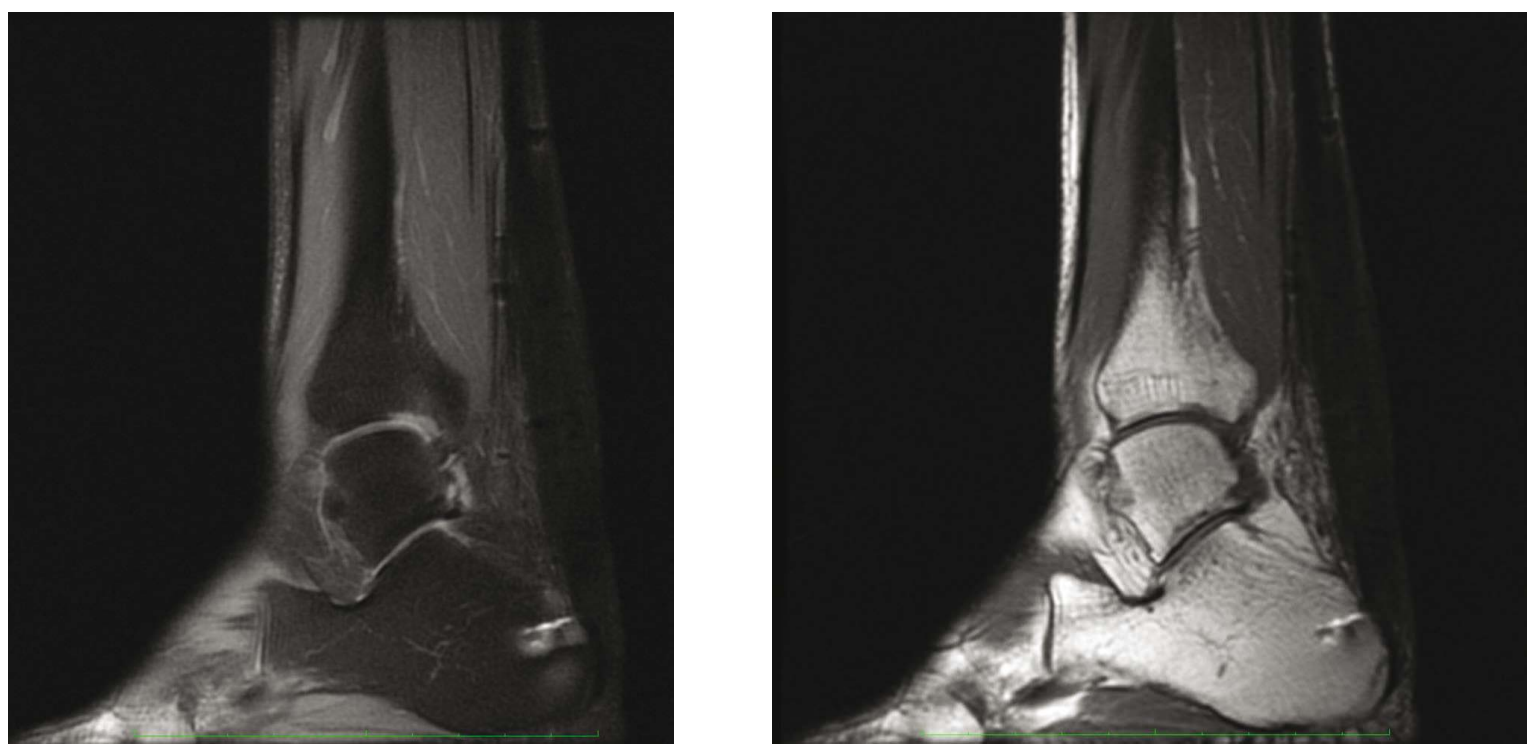

Fig. 12. MRI Evaluation of treatment results six months after the plastic surgery in patient no. 1

Рис. 12. МРТ Оценка результатов лечения через 6 месяцев после операции у первого пациента 
with an average injury-to-surgery time of 7 months. The average tendon loss measured intraoperatively was $6 \mathrm{~cm}$. They supported their work with an average follow-up period of 16 years. None of the patients ruptured the tendon again; two patients developed a superficial wound infection, which was reversed after oral antibiotic therapy. Postoperative gypsum was applied to the patients, in plantar flexion at 5 degrees, which lasted for 6 weeks. After this time, it was allowed to gradually apply weight to the operated leg, and rehabilitation started; after 2-3 weeks, the patients were allowed to apply full weight to the leg and gradually return to normal activities in about one month.

This work and our experience shows that V-Y plasty is an effective technique for the treatment of chronic Achilles tendon ruptures with accompanying major tendon continuity losses. In none of the cited works using this method has there been a recurrence of rupture. This technique has many advantages; it does not require grafting from another area, and thus does not require further mutilation nor does it require the use of synthetic materials.

However, we believe that the time taken to delay operated leg weight-bearing is too long. It is also unnecessary to immobilize the leg by means of a plaster dressing. The walking shoe perfectly meets the protective properties, increases the comfort of the patient's life, allows the patient to apply full weight

\section{Authors' contributions:}

Bartłomiej Kacprzak - study conception and design, acquisition and interpretation of data, drafting of manuscript, critical revision;

Mateusz Styk - interpretation of data, critical revision;

Natalia Siuba-Jarosz - interpretation of data, acquisition of data, drafting of manuscript.

All authors have read and agreed with the published version of the manuscript.

\section{Consent for publication}

The consent to participate was collected from the patients. They gave general consent for storage and further use of their data in the manuscript.

\section{Availability of data and materials}

The dataset supporting the conclusions of this article is available upon readers request - please contact corresponding author (n.siuba@ ortomedsport.pl).

\section{References}

1. Alfredson H., Spang C. Clinical presentation and surgical management of chronic Achilles tendon disorders - A retrospective observation on a set of consecutive patients being operated by the same orthopedic surgeon. Foot Ankle Surg. 2018;24(6):490494. https://doi.org/10.1016/j.fas.2017.05.011

2. Bochenek A., Reicher M. Human anatomy. Vol. 1. Warsaw: PZWL; 1990.

3. Maffulli N., Via A.G., Oliva F. Chronic Achilles Tendon Disorders: Tendinopathy and Chronic Rupture. Clin Sports Med. 2015;34(4):607-624. https://doi.org/10.1016/j.csm.2015.06.010

4. Boyd R.P., Dimock R., Solan M.C., Porter E. Achilles ten- to the operated leg starting from the first day after the surgery, without side effects. Immediate rehabilitation also did not result in any negative effects in the cases we have presented. It allowed the patients to quickly engage in normal life activities, which also resulted in the improvement of their well-being.

The 2017 study by Frankewycz et al. analyzed protocols and rehabilitation schemes from as many as 213 centers [9]. One hundred and seventeen (117) of them were notable for post-surgical procedures. There is no common consensus nor is there a gold standard for researchers regarding the postoperative rehabilitation scheme for Achilles tendon ruptures $[10,11]$. Several studies have focused on the effect of weight-bearing on the percentage of recurrent ruptures and the functional condition of the joint $[12,13]$. They do not show evidence that immediate joint weight-bearing had any negative impact on the tendon healing process nor did it result in its elongation. Furthermore, it does not predict recurrent ruptures.

Further studies in a larger number of patients with randomization are necessary in order to establish, first of all, a rehabilitation protocol that would be most beneficial to the patient and that would allow the patient to quickly return to life activities. As we have shown in our work, our unique protocol has delivered the results expected by the patients and relieved them of long-lasting pain and limitations.

\section{Вклад авторов:}

Кацпшак Бартломей - концепция и дизайн, сбор и интерпретация данных, написание текста статьи, редактирование;

Стик Матеуш - интерпретация данных, редактирование;

Сиуба-Ярош Наталия - интерпретация данных, сбор данных, написание текста статьи.

Все авторы прочитали и согласились с опубликованной версией рукописи.

\section{Согласие на публикацию}

Всеми пациентами было подписано информированное добровольное согласие на хранение и дальнейшее использование их данных в рукописи.

\section{Доступность данных и материалов}

Данные, подтверждающие информацию в этой статье, доступны по запросу читателей - пожалуйста, свяжитесь с автором (n.siuba@ortomedsport.pl).

don rupture: how to avoid missing the diagnosis. Br J Gen Pract. 2015;65(641):668-669. https://doi.org/10.3399/bjgp15X688069

5. Maffulli N., Via A.G., Oliva F. Chronic Achilles Tendon Rupture. Open Orthop J. 2017;11:660-669. https://doi.org/10.2174/ 1874325001711010660

6. Lin Y.J., Duan X.J., Yang L. V-Y Tendon Plasty for Reconstruction of Chronic Achilles Tendon Rupture: A Medium-term and Long-term Follow-up. Orthop Surg. 2019;11(1):109-116. https://doi.org/10.1111/os.12429

7. Deng S., Sun Z., Zhang C., Chen G., Li J. Surgical Treatment Versus Conservative Management for Acute Achilles Tendon Rupture: A Systematic Review and Meta-Analysis of Randomized Controlled Trials. J Foot Ankle Surg. 2017;56(6):1236-1243. 
https://doi.org/10.1053/j.jfas.2017.05.036

8. Guclu B., Basat H.C., Yildirim T., Bozduman O., Us A.K. Long-term Results of Chronic Achilles Tendon Ruptures Repaired With V-Y Tendon Plasty and Fascia Turndown. Foot Ankle Int. 2016;37(7):737-742. https://doi.org/10.1177/1071100716642753

9. Frankewycz B., Krutsch W., Weber J., Ernstberger A., Nerlich M., Pfeifer C.G. Rehabilitation of Achilles tendon ruptures: is early functional rehabilitation daily routine? Arch Orthop Trauma Surg. 2017;137(3):333-340. https://doi.org/10.1007/s00402017-2627-9

10. Carter T.R., Fowler P.J., Blokker C. Functional postoperative treatment of Achilles tendon repair. Am J Sports Med. 1992;20(4):459-462. https://doi.org/10.1177/036354659202000417
11. Yang X., Meng H., Quan Q., Peng J., Lu S., Wang A. Management of acute Achilles tendon ruptures: A review. Bone Joint Res. 2018; 7(10):561-569. https://doi.org/10.1302/2046-3758.710.BJR-2018-0004.R2

12. Costa M.L., MacMillan K., Halliday D., Chester R., Shepstone L., Robinson A.H., Donell S.T. Randomised controlled trials of immediate weight-bearing mobilisation for rupture of the tendo Achillis. J Bone Joint Surg Br. 2006;88(1):69-77. https://doi.org/10.1302/0301-620X.88B1.16549

13. Young S.W., Patel A., Zhu M., van Dijck S., McNair P., Bevan W.P., Tomlinson M. Weight-Bearing in the Nonoperative Treatment of Acute Achilles Tendon Ruptures: A Randomized Controlled Trial. J Bone Joint Surg Am. 2014;96(13):1073-1079. https://doi.org/10.2106/JBJS.M.00248

\section{Information about the authors:}

Bartłomiej Kacprzak, MD, Orto Med Sport, 28 Pułku Strzelców Kaniowskich 45 street, 90-640, Łódź, Poland. (hipokrates@op.pl)

Mateusz Styk, MD, Orto Med Sport, 28 Pułku Strzelców Kaniowskich 45 street, 90-640, Łódź, Poland. (m.styk@ortomedsport.pl)

Natalia Siuba-Jarosz ${ }^{*}$, MD, Orto Med Sport, 28 Pułku Strzelców Kaniowskich 45 street, 90-640, Łódź, Poland. ORCID: https://orcid.org/00000003-4316-1536 (n.siuba@ortomedsport.pl)

\section{Информация об авторах:}

Кацпшак Бартломей, врач клиники «Orto Med Sport», 90-640, Лодзь, Польша, ул. 28 Пулку Стшельцув Канёвских, 45. (hipokrates@op.pl)

Стик Матеуш, врач клиники «Orto Med Sport», 90-640, Лодзь, Польша, ул. 28 Пулку Стшельцув Канёвских, 45. (m.styk@ortomedsport.pl)

Сиуба-Ярош Наталия, врач клиники «Orto Med Sport», 90-640, Лодзь, Польша, ул. 28 Пулку Стшельцув Канёвских. ORCID: https://orcid.org/0000-0003-4316-1536 (n.siuba@ortomedsport.pl) 